Sonic Scope: New Approaches to Audiovisual Culture

\title{
Lorenzo Prati - Melting Buildings
}

Lorenzo Prati

Published on: Feb 15, 2021

DOI: 10.21428/66f840a4.ba69881c

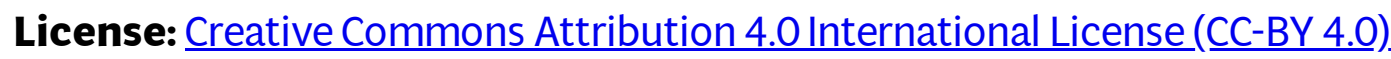




\section{Melting Buildings}

Lorenzo Prati, University of Sheffield

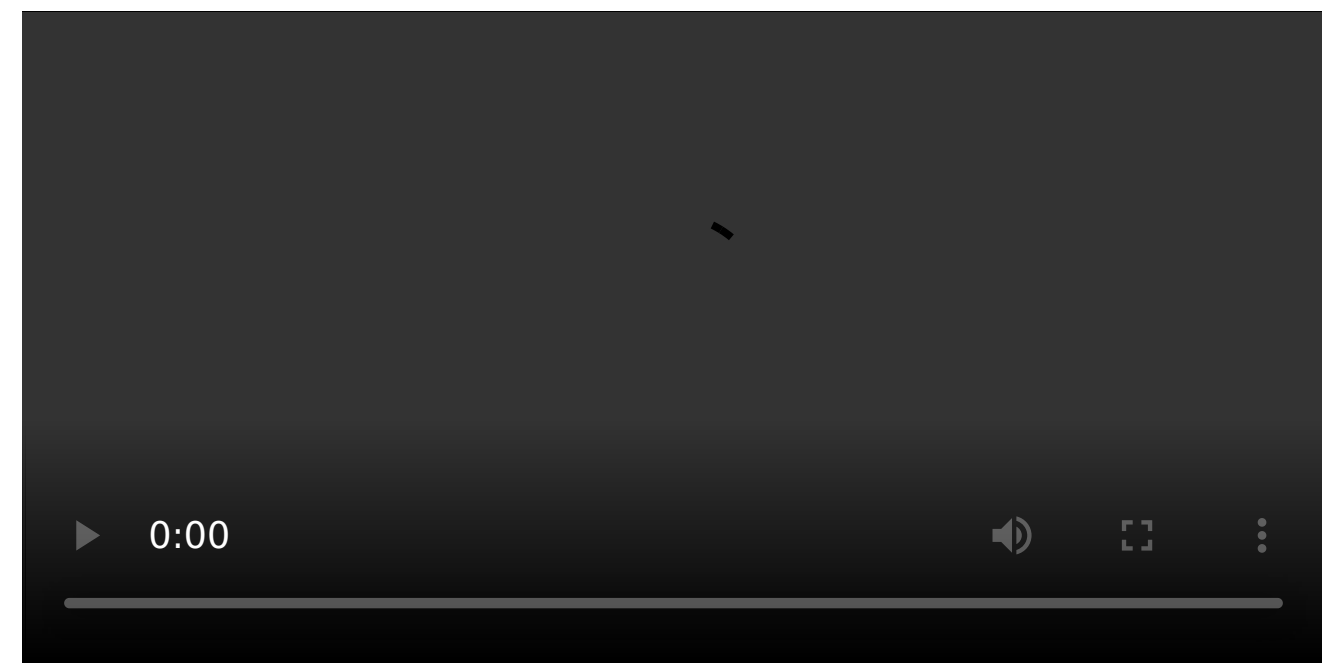

Melting Buildings, Lorenzo Prati. 